\title{
Weed Management Strategies in Direct Seeded Rice: A Review
}

Mohammad Hashim, V.K. Singh¹, K.K. Singh, Shiva Dhar ${ }^{1}$, U.C. Pandey

10.18805/ag.R-2245

\begin{abstract}
Rice (Oryza sativa) is a staple food of more than half of the population of the world and provides food security and livelihoods for millions of population. Direct seeding of rice (DSR) refers to the process of direct sowing the seeds in the field rather than by transplanting seedlings from the nursery. Direct seeded rice is an age old practice and before the introduction of green revolution in India. Rainfed rice was often broadcasted into moist soil and crops were highly prone to weed competition resulted into low yield. Rice ecosystems and establishment methods determined the weed spectrum and degree of infestation in rice field (DSR). Weeds are considered as a major biological constraint in direct seeded rice. In direct seeded rice, weed management depend on weed flora, critical period of weed control, availability of water and method to be adopted. Integrated weed management (IWM) is essential to achieve the long term, sustainable and economic management of weeds in direct seeded rice. The literature regarding the direct seeded rice, critical period of crop weed competition, different types of weed flora and different methods for the effective and sustainable management of weeds in direct seeded rice are reviewed in this paper.
\end{abstract}

Key words: Direct-seeded rice, IWM, Weeds, Weed flora, Weed management, Weed shifting.

Rice (Oryza sativa L.) is a major cereal crop is regarded as staple food by majority of world's population and about $90 \%$ of the world's rice is produced and consumed in Asia only (FAO, 2014). In India, it is grown on an area of about 43.66 $\mathrm{m}$ ha with a total production of $118.87 \mathrm{~m}$ t during 2019-20 (Anonymous, 2020-21). More than half of the world's population depends on rice for their daily sustenance (Chauhan and Johnson 2011a) and it is the primary source of income and employment for more than 100 million households in Asia (Singh et al., 2016). To meet the world's increasing demand of rice in a sustainable way with shrinking natural resources is a great challenge. To ensure good crop establishment rice is predominantly grown by transplanting after puddling and kept flooded for most part of the growing season (Singh et al., 2016) and it has been a major traditional method of rice establishment. Puddling adversely affects soil physical properties and requires a large amount of water, labour and more energy to achieve proper soil tilth for succeeding crops. Excessive pumping of water for puddling in most part of the rice growing areas, water table has been declining. Water scarcity in most of the rice growing areas of India and labour costs have increased dramatically due to migration of labours from rural areas to cities as well as non agricultural sectors of rural economy (Chauhan, 2012a and Singh et al., 2016). Production of rice with conventional transplanting method has been limited by a number of factors such as water scarcity, high input and labour costs, shortage of skilled labour resulting into low rice yield. In DSR system, dry rice seeds are sown with or without tillage and irrigation is applied periodically to maintain soil at field capacity.

Faster and easier planting, improve soil health, higher tolerance to water deficit, less methane emission and often higher profit in areas with an assured water supply (Kumar and Ladha 2011). Weed competition reduced
ICAR-Indian Agricultural Research Institute, Regional Station, Pusa848 125, Bihar, India.

${ }^{1}$ ICAR-Indian Agricultural Research Institute, New Delhi-110 012, India.

Corresponding Author: Mohammad Hashim, ICAR-Indian Agricultural Research Institute, Regional Station, Pusa-848 125, Bihar, India. Email: hashimagronomy@gmail.com

How to cite this article: Hashim, M., Singh, V.K., Singh, K.K., Dhar, S. and Pandey, U.C. (2022). Weed Management Strategies in Direct Seeded Rice: A Review. Agricultural Reviews. DOI: 10.18805/ag.R-2245.

Submitted: 22-04-2021 Accepted: 13-12-2021 Online: 29-01-2022 multiple rice yield components and weed biomass in wetseeded rice was six-fold greater that in rice transplanted into puddled soil and twice as much again in dry-seeded rice sown either after dry tillage or without tillage (Singh et al. 2011). Weed problem is sought to be addressed from two basic points of view: weed control and weed management. Weed control approach only emphasizes on reduction of weed pressure and in contrary the management approach focuses on keeping weed infestation at economic threshold level which are compatible with environmentally and economically sustainable production. Different weed control options are available for rice such as physical, chemical and biological control. Physical control is eco-friendly but labour intensive and delayed in weeding due to unavailability of sufficient labour in time. Biological control by using different bio-agents and mycoherbicides are practiced in irrigated lowland rice, but these may not be effective under aerobic soil conditions. Chemical control, on the contrary, is the most effective, economic and practical way of weed management (Hussain et al. 2008, Anwar et al. 2012a). 
Though, to overcome these challenges, direct seeding of rice (DSR) seems promising under several ecologies and production systems and is considered as viable and potential alternative to PTR (Puddled Transplanted Rice).

\section{Yield losses due to weeds in DSR}

Direct seeded rice (DSR) is a cost effective rice establishment method where dry seed are directly drilled into the unpuddled soil. It provides opportunities of saving irrigation water by $12-35 \%$, labour up to $60 \%$ and provides higher net returns with at par yield than transplanted rice (Kumar and Ladha, 2011). In addition to higher economic returns, DSR is shorter duration, less labour intensive, consume less water (Bhushan et al. 2007) and have less methane emissions (Wassmann et al. 2004). Despite multiple benefits of dry direct seeded rice, weed control remains one of the major challenges for its success in South Asia (Kumar and Ladha, 2011; Rao et al., 2007; Singh et al., 2008). Weed control is more difficult in dry- DSR than conventional tillage (CT)- Transplanted rice (TPR) because weeds emerge with rice seedlings in dry-DSR which are less competitive than 30-35 days old rice seedlings use in CT- TPR and initial flooding used in CT-TPR helps in weed control but it is lacking in dry- DSR (Kumar and Ladha, 2011).

Weeds adversely affected yield, quality and cost of production as a result of competition for various growth factors in DSR system. Extent of loss due to weeds may vary depending upon cultural methods, rice ecosystems, management practices, cultivars, weed species and their association, growth rate, their density and duration of cropweed competition. The weeds do compete with crop for various growth factors, viz. nutrients, moisture, light and space resulting into greatest loss (Walia 2006). Globally, actual yield losses due to pests have been estimated $\sim 40 \%$, of which weeds caused the highest loss (32\%) (Rao et al. 2007). Yield reduction due to weeds is more critical in directseeded rice than in transplanted rice (Karim et al. 2004). Red rice (Oryza sativa f.sp. spontanea) is highly competitive and causes severe rice yield losses ranging from $15 \%$ to $100 \%$ (Farooq et al. 2009). On average, estimated losses from weeds in rice are around $10 \%$ of total grain yield; however, can be in the range of 30 to $90 \%$, reduces grain quality and enhances the cost of production (Rao et al. 2007). Season-long weed competition in direct- seeded aerobic rice may cause yield reduction up to $80 \%$ (Sunil et al. 2010). On an average, yield loss, due to weed competition ranges from 15 to 20 per cent, but in severe cases it may exceed 50 per cent (Hasanuzzaman et al., 2009). In case of heavy infestation and extreme cases, weed infestation may cause complete failure of aerobic rice (Jayadeva et al. 2011). Thus direct-seeded aerobic rice is highly vulnerable to weeds compared with other rice ecosystems (Anwar et al. 2011).

\section{Critical period of crop-weed competition}

The critical period for crop-weed competition refers to the period from sowing of crop upto which it has to be maintained in a weed free environment for remunerative crop production. Weed control during the critical period is essential to reduce the weed competition and for effective utilization of available resources for enhanced productivity and profitability. Due to alternate events of wetting and drying and emergence of weeds and rice simultaneously, crop-weed competition is more severe in DSR than in transplanted rice. The severity of competition depends not only on competing species but also on its density, duration and the fertility status of the soil. In DSR, it is important to minimize the crop-weed competition during the early stages of the crop before it forms a closed leaf canopy (Singh 2008). In DSR, the critical period of weed competition has been reported to be 14- 41 days after sowing (Chauhan and Johnson, 2011b). Azmi et al. (2007) reported that critical period for weed control under mixed weed infestation in DSR was from 12 to 60 DAS. In aerobic rice cultivation, weed free condition during the initial crop growth period (upto 35 DAS) is critical which has the potential to reduce grain yield drastically.

\section{Major weed flora in DSR}

The DSR crop faces severe challenges from weeds and effective weed management is essential for successful rice production from DSR. About 350 species have been reported as weeds of rice, of which grasses are ranked as first posing serious problem followed by sedges and broad-leaf weeds causing major losses to rice production worldwide (Singh et al., 2016). In DSR, fields are dominated by different grasses, sedges and broad leaf weeds (BLW) and weed flora will vary depending on the season, climatic and edaphic conditions. Among major grassy weeds Echinochloa colona (L.), Echinochloa crusgalli (L.), Leptochloa chinensis (L.), Oryza sativa L. f. spontanea Roshev and Ischaemum rugosum Salisb causes major yield loss. Echinochloa colona and $E$. crusgalli are the most serious weeds affecting DSR. The density of these weeds in DSR depends upon moisture condition in the field. E. colona requires less water, so it is more abundant in DSR (Singh et al., 2016). Sedges causing major yield losses are Cyperus iria, Cyperus difformis L., Schoenoplectus juncoides. Broad-leaves weeds (BLW) causing major yield losses are Eclipta prostrata (L.), Spheoclea zeylanica Gaertner and Ludwigia hyssopifolia (G. Don.) Excell. Raj et al., (2013b) reported that in Kuttanad, during kharif season BLW predominate (39.3 per cent) followed by sedges (38.9 per cent) and grassy weeds (21.8 per cent) while in rabi season sedges predominate (96.8 per cent) followed by BLW (2.7 per cent) and grasses $(0.5$ per cent). During the first 30 days after sowing, broad-leaf weeds dominated the grassy weeds and sedges, contributing more than $62 \%$ of the total weed population. At later stages, grasses dominated over non-grasses and sedges, contributing more than $90 \%$ of the total weed population at 75 DAS, at which E. colona alone contributed more than $80 \%$ of the total weed population at 60 DAS and beyond (Singh 2008). Changes in crop establishment, from transplanting to direct seeding also resulted in marked 
changes in the composition of weed flora (Singh et al., 2008). Direct seeding increased the population of annual grasses such as Echinochloa crusgalli, Echinochloa colona and Leptochloa chinensis, perennial sedge Cyperus rotundus and BLW such as Commelina diffusa and Caesulia axillaris (Singh et al., 2008). Adoption of direct seeding technology may result in weed flora shifts towards more difficult to control and competitive grasses and sedges (Kumar and Ladha, 2011).

\section{Weed management strategies in DSR Weed prevention methods}

This method restricts introduction and spread of weeds and is the most basic of all weed control methods (Buhler, 2002). It includes using weed-free seeds, maintaining clean fields, borders and irrigation canals and cleaning farm equipments (Datta and Baltazar, 1996). Rice seeds contaminated with weed seeds may introduce problematic weed species to a new field and enrich the soil weed seed bank. In addition to clean crop seed, the machinery used for tillage, sowing, harvesting, or threshing operations should also be cleaned before moving it from one field to another. Bunds and irrigation canals free from weeds may also help to reduce the spread of weed seeds through irrigation water (Hossain et al., 2016).

\section{Cultural methods}

Cultural practices play significant role to determine the cropweeds competition for above ground and below ground resources and hence influence weed management (Grichar et al., 2004 and Dass et al., 2016). Some cultural practices like selection of cultivars, stale seedbed technique, tillage, seeding density, crop residue, crop rotation, intercropping, cover crops, fertilizer management and water management etc to be used in DSR could be a good alternative to control weeds.

\section{(A) Land leveling}

Land levelling is essential to achieve uniform crop stand before sowing. Levelling is usually done by using a wooden or metal board. However, laser land levelling ensures better crop establishment (Jat et al., 2009), precise water control and increased herbicide use efficiency (Chauhan, 2012a). Laser land levelling reduces the weed population by up to 40 per cent and the labor requirement for weeding by 75 per cent (Rickman, 2002) and 86.7 per cent compared to traditional method of land levelling (Banerjee, 2015).

\section{(B) Selection of cultivars}

Cultivars to be used in DSR could be a good alternative to control weeds. Rice cultivar having strong weed competitiveness is deemed to be a low cost safe tool for weed management in DSR (Gibson and Fischer, 2004). In general, tall and traditional cultivars with high tillering ability, high early growth rate, high leaf area index and specific leaf area, long leaves and droopy plant type are more weed suppression ability than short-statured early maturing, modern cultivars with erect leaves Early maturing rice cultivars and rice hybrids also have a smothering effect on weeds due to improved vigour and having the tendency of early canopy cover (Mahajan et al. 2011). Rice hybrids are more competitive and usually have better vigor than inbreds and effectively suppressed the infestation of Echinochloa spp. and helped reduce herbicide dependency (Gibson et al., 2001). Rice cultivars having good mechanical strength in the coleoptiles to facilitate early emergence of the seedlings under crust conditions (generally formed after light rains), early seedling vigour for weed competitiveness (Zhao et al., 2006), higher tiller number (Fischer et al., 1997), rapid canopy ground cover (Lotz et al., 1995) and yield stability over planting times are desirable traits for DSR. Rice cultivars having allelopathic effect can contribute to weed suppression. Kumar et al. (2013) reported that variety Gautam was highly competitive in suppressing the Echinochloa spp compared to the Prabhat and Krishna Hamsa.

\section{(C) Stale seedbed technique}

Stale seedbed technique is an important cultural practice and a method of weed control where weeds are allowed to germinate and the emerged weed seedlings are killed by shallow tillage or using a non selective herbicide that can be used to reduce the weed seed bank. Those weed species that have low initial dormancy and are present in the top soil layers are more conducive to be controlled by this practice, such as Eclipta prostrate, Leptochloa chinensis, Ludwigia hyssopifolia and Digitaria ciliaris. The use of the stale seedbed practice could also help to reduce the problems of some hard weeds, such as Cyperus rotundus, weedy rice and volunteer rice seedlings (Chauhan, 2012). Singh et al. 2009 reported 53\% lower density in Dry- DSR after a stale seed bed than without this practice. Stale seedbed combined with herbicide (paraquat) and zero-till results in better weed control of Cyperus iria, Cyperus difformis, Fimbristylis miliacea (L.) Vahl, Leptochloa chinensis and Eclipta prostrata because of low seed dormancy of weeds and their inability to emerge from a depth greater than $1 \mathrm{~cm}$ (Chauhan and Johnson, 2008; Chauhan and Johnson 2010).

\section{(D) Tillage}

Tillage can affect weed species through the changes and disturbances in weed seed distribution in the soil. Primary tillage can reduce annual weed species, especially when planting is delayed to allow weed seeds to emerge before final tillage (Buhler and Gunsolus, 1996). On the other hand, zero tillage favors weed infestation. Conservation tillage has been criticized particularly in relation to lower yields and perennial weed problems which results in an increase in herbicide application (Singh et al. 2011). Zero tillage DSR had more equivalent yield than DSR CT. Another study recorded that the direct-seeded $\mathrm{ZT}$ gave at par yield as compared with transplanted (TP) rice (Singh et al. 2008). 
Shallow tillage before crop emergence and post plant tillage after crop establishment help to remove annual weeds and inhibit the growth of perennial weeds (Buhler, 2002).

\section{(E) Seed rate and spacing}

Seed rate and spacing influence the weed population. Higher seeding rate of rice has been advocated not only for weed control but also for avoiding higher risk of poor seedling establishment (Anwar et al., 2011). Higher seeding rates would be beneficial if no weed control is planned or if only partial weed control is expected. A quadratic model predicted that seeding rates of $48-80 \mathrm{~kg} / \mathrm{ha}$ for the inbred varieties and $47-67 \mathrm{~kg} / \mathrm{ha}$ for the hybrid varieties were needed to achieve maximum grain yield when grown in the absence of weeds, while rates of $95-125 \mathrm{~kg}$ seed/ha for the inbred varieties and $83-92 \mathrm{~kg}$ seed/ha for the hybrid varieties were needed to achieve maximum yields in competition with weeds. Such high seeding rates may be prohibitive when using expensive seed and maximum yields are not the only consideration for developing recommendations for optimizing economic returns for farmers (Chauhan et al. 2011). Weeds grown in wider rows may have greater biomass than weeds grown in narrow rows. Therefore, a direct-seeded crop should be grown using narrow row spacing to obtain faster canopy closure and less penetration of light and ultimately less weed growth (Chauhan, 2012b).

\section{(F) Crop residue and Sesbania co-culture (Brown Manuring)}

Crop residues have a chemical and physical effect on the growth of crops and weeds by reducing sunlight and modifying soil temperature. Seedlings of many weed species can be suppressed by using crop residue as mulches (Chauhan, 2012b). Growing sesbania as a green manure with rice is called brown manuring (sesbania co-culture). After 25-30 days of growth sesbania is killed with 2, 4-D ester at $0.5 \mathrm{~kg} \mathrm{ha}^{-1}$. This co-culture technology can reduce the weed population by nearly half without any adverse effect on rice yield (Singh et al., 2007 and Dhyani et al. 2007). These residues may not only help in suppressing weed emergence but also add fertility to the soil. Sesbania coculture was more effective against BLW and sedges and less effective on grasses. So, it is recommended to use pendimethalin as pre-emergence to overcome the problem of grass weeds in this technique (Kumar and Ladha, 2011).

\section{(G) Seed priming and seed quality}

Quality seeds which are free from any contaminants might be an important approach to manage weeds in DSR systems. A robust seedling stand obtained from primed seeds enhanced rice competitiveness against weeds (Anwar et al., 2012). Juraimi et al. (2012) reported that priming treatments also produced the most vigorous seedlings with 50 per cent more vigour index compared to unprimed seeds. Higher and synchronized emergence of primed seeds can ensure vigorous crop stand with rapid canopy development giving rice plants a preliminary advantage over weeds (Anwar et al., 2012). Relative yield loss was reduced by around 10 per cent due to priming (Juraimi et al., 2012). This was mainly due to the fact that priming reduces the risk of poor stand establishment and crop losses due to weeds.

\section{(H) Crop rotation}

Crop rotation considered as a vital tool of weed management and helps in breaking the weed seed cycle as well as facilitating the identification of weedy rice and it leads to better control. Effective control of weedy rice can be obtained by rotating the rice crop with other crops, such as soybean, mungbean, cotton, maize, etc., which allow using other herbicides and cultural practices that cannot be used in rice (Singh et al., 2013). Planting mung bean in dry season in Northern India also reduced weed growth and weeding time and increased herbicide performance (Mahajan et al. 2012).

\section{(I) Intercropping and cover crops}

Intercropping can reduce both weed density and biomass to a great extent due to decreased light transmission through the canopy Intercropping for 30 days were found effective in controlling weeds in DSR (Singh et al., 2007). Incorporation of cover crop into the soil may add allelochemicals to the soil to prevent germination and establishment of weeds and decreased light transmission to the ground (Buhler, 2002). Intercropping with Sesbania for 30 days were found effective in controlling weeds in DSR (Singh et al., 2007a).

\section{(J) Fertilizer management}

Fertilizer management can definitely alter the competitive balance between crops and weeds and should be aimed at maximizing nutrient uptake by crop and minimizing nutrient availability to weeds. Manipulation of crop fertilization is a promising approach to reduce weed infestation and may contribute to long-term weed management (Blackshaw et al. 2004). Weeds become less competitive when $N$ was applied at early growth stages of crop compared with later application and weeds are found to be more responsive to added $\mathrm{N}$ than that of crop (Blackshaw et al., 2000 and Buhler, 2002). When weeds were controlled, rice crop responded to higher amount of $\mathrm{N}$ application but under weedy and partially-weedy conditions, grain yield reduced drastically with higher amount of $\mathrm{N}$ fertilization (Mahajan and Timsina, 2011).

(K) Water management: Every weed species has an optimum soil moisture level, below or above which its growth is hampered and therefore time, depth and duration of flooding could play an important role in suppressing weeds in DSR system. Good water management together with chemical weed control offers an unusual opportunity for conserving moisture and lowering the cost of rice production (Rao et al. 2007).

\section{Physical methods}

Manually or mechanically control of weeds are called physical control of weeds. Hand weeding is very easy and environment-friendly but tedious and highly labor intensive 
and thus is not an economical for the farmers (Juraimi et al., 2013). Mechanical weeding using hand pushed weeders is feasible only where rice is planted in rows; however, weeds emerging within rows are difficult to remove with these weeders (Chauhan, 2012b).

\section{Chemical methods}

Due to scarcity of labour during the critical period of weed competition, high labour cost and unfavourable weather at weeding time manual and mechanical methods could not find much place among farmers and not economical. Under such situation, most effective, economical and practical way of weed management is the use of weedicides (Hussain, 2008). Herbicides may be considered to be a viable alternative to hand weeding due to scarcity and high wages of labour (Chauhan and Johnson, 2011a; Anwar et al., 2012a). Singh et al. (2004) reported that a ready mix formulation of metsulfuron methyl + chlorimuron ethyl was very effective against diverse weed flora. Singh et al. (2010) found effective control over the density of $C$. rotundus with the application of azimsulfuron + Metsulfuron-methyl. Application of penoxsulam at 20, 22.5 and $25 \mathrm{~g} / \mathrm{ha}$ have better control over the density of grasses and broad-leaf weeds in DSR (Singh et al. 2012). Lowest population of $E$. colona was recorded with application of pendimethalin at $2.0 \mathrm{~kg}$ while of $C$. axillaris was with combined application of bentazone with pendamethalin (Singh et al. 2005). Singh et al. (2016) also reported that treatments with pendimethalin PRE fb bispyribac-sodium + azimsulfuron POST had lower weed biomass at 45 days after sowing (DAS). Highest grain yield of scented basmati rice $\left(3.43 \mathrm{tha}^{-1}\right)$ was recorded with the sequential application of pendimethalin PRE $\mathrm{fb}$ bispyribac-sodium + azimsulfuron POST. Applying oxadiargyl by mixing with sand onto flooded field was less effective than spray applications in non-flooded field. Other herbicides that are found effective in DSR are pyrazosulfuron and oxadiragyl as pre-emergence and azimsulfuron, penoxsulam, cyhalopfop-butyl and ethoxysulfuron as postemergence (Rao et al. 2007).

Due to narrow spectrum activity of single herbicides these are seldom furnishes satisfactory and season long weed control. Herbicides with different mode of action when mixed together, bind to different target sites in weeds and prevent the probability of target site resistance in susceptible species (Paswan et al. 2012). Chauhan and Yadav (2013) opined that in future, the combination of two or more herbicides may become a part of an effective and integrated approach to achieve more satisfactory control of complex weed flora in DSR. Lap et al. (2013) revealed that combination products containing penoxsulam and cyhalofop butyl increased the rice productivity in direct seeded systems. Raj et al. (2013a) reported that the application of bispyribac sodium + metamifop 14 per cent SE @ 70 g ha1 + PIW -111 wetter, 10 -15 DAS resulted in enhanced rice yield in wet DSR.

\section{Biological methods}

It involves utilization of natural living organisms such as insects, pathogens and competitive plants to limit the weed infestation. Different herbivorous bio-agents such as fish, tadpoles, shrimps ducks and pigs are used to control weeds in irrigated lowland rice but these cannot be used in the area where there is no standing water. The main objective of the biological control is reduction and regulation of the weed population below the level of economic injury. Weed control by micro herbicides are now being studied to reduce herbicide dependency. COLLEGO, a powder formulation of Colletotrichum gloeosporioides (Penz.) Sacc. f. sp. Aeschynomene for the control of Aeschynomene virginica (L.) in rice. The endemic fungus Colletotrichum gloeosporioides $f$. sp. jussiaeae (C.g.j.) controlled $>80$ per cent of water primrose in rice after four weeks (Boyette et al., 1979). Thi et al., 1999 reported that myco-herbicides using most promising fungi e.g. Exserohilum monocerus and Cocholiobolus lunatas found to control barnyard grass. Setosphaeria $s p$. and $C$. rostrata were also found to control Leptochloa chinensis effectively without causing any damage to rice plant.

\section{Integrated weed management}

Various agronomic tools have been evaluated for managing weeds. But, all the agronomic tools may not work perfectly with every crop or weed species. Integration of higher seed rate and spring-applied fertilizer in conjunction with limited herbicide use managed weeds efficiently and maintained high yields (Blackshaw et al., 2005). Adoption of IWM approach for sustainable rice production has been advocated by many researchers (Sunil et al. 2010, Jayadeva et al. 2011). Sequential application of pre-emergence herbicides such as pendimethalin, in dry seeded rice or early post-emergence application of anilofos/thiobencarb for the control of annual grasses in wet-seeded rice and postemergence application of 2, 4-D against sedges and nongrassy weeds in wet and dry-seeded rice may be a better option than the use of one herbicide.

\section{CONCLUSION}

Direct seeded rice appears to be a viable alternative to overcome the problem of labour and water shortage and it has a potential to produce slightly lower or comparable yields as that of transplanted rice. Weeds however are the major biological constraint in direct seeded rice production. To achieve effective, long term and sustainable weed control in direct-seeded system, all suitable management techniques are to be wisely utilized in such a compatible way as to reduce the weed population below the economic threshold levels and to deplete the weed seed bank from the soil and enable rice crop to be more competitive by either delaying the emergence or suppressing the weed emergence and growth. The use of any single strategy cannot provide effective, season-long and sustainable weed control. To achieve this goal there is a need to integrate the 
use of different weed management strategies, such as cultural (selection of cultivars, stale seedbed technique, tillage, seed rate and spacing, crop residue, quality seed with priming, crop rotation, intercropping, cover crops, fertilizer and water management), physical (manual and mechanical), chemical (appropriate herbicide mixtures, timing and rotation) and biological (use of different bioagents, insects etc.) weed management practices.

\section{REFERENCES}

Anonymous (2020-21). Area and Production of Rice in India. http// www.indiastat.com.

Anwar, M.P., Juraimi, A.S., Puteh, A., Man, A. and Rahman, M.M. (2012a). Efficacy, phyto-toxicity and economics of different herbicides in aerobic rice. Acta Agriculturae Scandinavica. 62: 604-615.

Anwar, M.P., Juraimi, A.S., Puteh, A., Selamat, A., Man, A. and Hakim, M.A. (2011). Seeding method and rate influence on weed suppression in aerobic rice. African Journal of Biotechnology. 10(68):15259-15271.

Anwar, M.P., Juraimi. A.S., Puteh, A., Selamat, A., Rahman, M.M. and Samedani, M. (2012). Seed priming influences weed competitiveness and productivity of aerobic rice. Acta Agriculturae Scandinavica. 62: 499-509.

Azmi, M., Juraimi, A.S. and Mohammad Najib, M.Y. (2007). Critical period of weedy rice control in direct seeded rice. Journal of Tropical Agriculture and Food Science. 35: 319-332.

Banerjee, A. (2015). Farmers get quick wins from laser levelling. Available: csia.org/farmers-get-quick-wins-from-laserlevelling/ [20 December 2016].

Bhushan, L., Ladha, J.K., Gupta, R.K., Singh, S., Tirol-Padre, A., Saharawat, Y.S., Gathala, M. and Pathak H. (2007). Saving of water and labor in a rice-wheat system with no-tillage and direct seeding technologies. Agronomy Journal. 99: 1288-1296.

Blackshaw, R.E., Molnar, L.J. and Janzen, H.H. (2004). Nitrogen fertilizer timing and application method affect weed growth and competition with spring wheat. Weed Science. 52: 614-622.

Blackshaw, R.E., Moyer, J.R., Harker, K.N. and Clayton, G.W. (2005). Integration of agronomic practices and herbicides for sustainable weed management in a zero-till barley field pea rotation. Weed Technology. 19: 190-196.

Blackshaw, R.E., Semach, G., Li, X., O'Donovan, J.T. and Harker K.N. (2000). Tillage, fertilizer and glyphosphate timing effects on foxtail barley management in wheat. Canadian Journal of Plant Science. 80: 655-660.

Boyette, C.D., Templeton, G.E. and Smith, Jr. R.J. (1979). Control of winged water primrose (Jussiaea decurrens) and northern joint vetch (Aeschynomene virginica) with fungal pathogens. Weed Science. 27: 497-501.

Buhler, D.D. (2002). Challenges and opportunities for integrated weed management. Weed Science. 50: 273-280.

Buhler, D.D. and Gunsolus, J.L. (1996). Effect of date of pre-plant tillage and planting on weed populations and mechanical weed control in soybean (Glycine max L). Weed Science. 44: 373-379.
Chauhan, B.S. and Yadav, A. (2013). Weed management approaches for dry seeded rice in India- A review. Indian Journal of Weed Science. 45: 1-6.

Chauhan, B.S. (2012a). Weed ecology and weed management strategies for dry-seeded rice in Asia. Weed Technology. 26: $1-13$.

Chauhan, B.S. (2012b). Weed Management in Direct Seeded Rice Systems. Los Baños (Philippines): International Rice Research Institute. 20p.

Chauhan, B.S. and Johnson, D.E. (2010). The role of seed ecology in improving weed management strategies in the tropics. Advances in Agronomy. 105: 221-262.

Chauhan, B.S. and Johnson, D.E. (2008). Germination ecology of Chinese sprangletop (Leptochloa chinensis) in the Philippines. Weed Science. 56: 820-825.

Chauhan, B.S. and Johnson, D.E. (2011a). Growth response of direct seeded rice to oxadiazon and bispyribac-sodium in aerobic and saturated soils. Weed Science. 59: 119122.

Chauhan, B.S. and Johnson, D.E. (2011b). Row spacing and weed control timing affect yield of aerobic rice. Field Crop Research. 121: 226-331.

Chauhan. B.S., Singh, V.P., Kumar, A. and Johnson, D.E. (2011). Relations of rice seeding rates to crop and weed growth in aerobic rice. Field Crops Research. 21: 105-115.

Dass, A., Shekhawat, K., Choudhary, A.K. Sepat, S., Rathore, S.S., Mahajan, G. and Chauhan, B.S. (2016). Weed management in rice using crop competition- A review. Crop Protection. Available: http://dx.doi.org/10.1016/j.cropro.2016.08.005 [20 December 2016].

De Datta, S.K. and Baltazar, A.M. (1996). Weed Control Technology as a Component of Rice Production Systems. In: Weed Management in Rice. [Auld B.A., Kim K.U. (Eds)]. FAO Plant Production and Protection Paper 139, Rome, Italy. pp. 27-52.

Dhyani, V.C., Singh, V.P., Singh, S.P., Tripathi, N., Kumar, A. and Singh, K. (2007). Sesbania Brown Manuring: A Tool for Plant Establishment and Weed Management in Direct Seeded Rice. In: Biennial Conference of Indian Society of Weed Science, CCS Haryana Agriculture University, Hisar, November, 2-3. p. 49.

FAO (2014-15). A Regional Rice Strategy for Sustainable Food Security in Asia and the Pacific. Rap Publication, 2014/05.

Farooq, M., Basra, S.M.A., Ahmad, N. and Murtaza, G. (2009). Enhancing the performance of transplanted course rice by seed priming. Paddy and Water Environment. 7: 5563.

Fischer, A.J., Ramirez, H.V. and Lozano, J. (1997). Suppression of jungle rice (Echinochloa colona (L.) Link) by irrigated rice cultivars in Latin America. Agronomy Journal. 89: 516-552.

Gibson, K.D, Hil, J.E., Foin, T.C., Caton, B.P. and Fischer, A.J. (2001). Water seeded rice cultivars differ in ability to interfere with water grass. Agronomy Journal. 93: 326332.

Gibson, K.D. and Fischer, A.J. (2004). Competitiveness of Rice Cultivars as a Tool for Crop-based Weed Management. In: Weed Biology and Management. (Ed. Inderjit) Kulwer Academic Publishers, the Netherlands. pp. 517-537. 
Grichar, W.J, Bessler, B.A. and Brewer, K.D. (2004). Effect of row spacing and herbicide dose on weed control and grain sorghum yield. Crop Protection. 23: 263-267.

Hasanuzzaman, M., Ali, M.H., Akther, M. and Alam, K.F. (2009). Evaluation of pre-emergence herbicide and hand weeding on the weed control efficiency and performance of transplanted Aus rice. American and Eurasian Journal of Agronomy. 2: 138-143.

Hossain, M.M., Begum, M., Rahman, M.M. and Akanda, M.M. (2016). Weed management on direct-seeded rice system - A review. Progressive Agriculture. 27: 1-8.

Hussain, S., Ramzan, M., Akhter, M. and Aslam, M. (2008). Weed management in direct seeded rice. Journal of Animal and Plant Science. 18(2-3): 86-88.

Jat, M.L., Gathala, M.K., Ladha, J.K., Saharawat, Y.S., Jat, A.S., Vipin, K., Sharma, S.K., Kumar, V. and Gupta, R.K. (2009). Evaluation of precision land leveling and double zero-till systems in the rice-wheat rotation: Water use, productivity, profitability and soil physical properties. Soil and Tillage Research. 105: 112-121.

Jayadeva, H.M., Bhairappanavar, S.T., Hugar, A.Y., Rangaswamy, B.R., Mallikarjun, G.B., Malleshappa, C. and Naik, D.C. (2011). Integrated weed management in aerobic rice (Oryza sativa L.). Agriculture Science Digest. 31: 58-61.

Juraimi, A.S,, Saiful, A.H.M., Uddin, M.K., Anwar, M.P. and Azmi, M. (2013). Sustainable weed management in direct seeded rice culture: A review. Australian Journal of Crop Science. 7(7): 989-1002.

Juraimi, A.S., Anwar, M.P., Selamat, A., Puteh, A. and Man, A. (2012). The influence of seed priming on weed suppression in aerobic rice. Pakistan Journal of Weed Science Research. 18: $257-264$.

Karim, S.M.R., Man, A.B. and Sahid, I.B. (2004). Weed problems and their management in rice fields of Malaysia: An overview. Weed Biology and Management. 4: 177-186.

Kumar, P., Singh, Y. and Singh, U.P. (2013). Evaluation of cultivars and herbicides for control of barnyard grass and nut sedge in boro rice. Indian Journal of Weed Science. 45: 76-79.

Kumar, V. and Ladha, J.K. (2011). Direct seeding of rice: recent developments and future research needs. Advances in Agronomy. 111: 299-360.

Lap, N., Somsak, S., Yuli, I.M. Duy, L., Choy, L.L., Victoria, E.B., Niranjan, B.V. and Mann, R.K. (2013). Efficacy and Rice Tolerance to Penoxsulam + Cyhalofop Herbicide Mixtures in Asean Countries [abstract]. In: Programme and Abstracts, 24 ${ }^{\text {th }}$ APWSS Conference, 22-25 October, Padjadjaran University Convention Hall, Bandung, West Java, Indonesia, pp.97.

Lotz, L.A.P., Wallinga, J. and Kropff, M.J. (1995). Crop-weed Interactions: Quantification and Prediction. In: Ecology and Integrated Farming Systems, [Glen, D.M., Greaves, M.P. and Anderson, H.M. (eds)], Wiley and Sons, Chichester, U.K., pp. 31-47.

Mahajan, G. and Timsina, J. (2011). Effect of nitrogen rates and weed control methods on weeds abundance and yield of direct-seeded rice. Archives of Agronomy and Soil Science. 57: 239-250.
Mahajan, G., Chauhan, B.S., Timsina, J., Singh, P.P. and Singh, K. (2012). Crop performance and water- and nitrogenuse efficiencies in dry-seeded rice in response to irrigation and fertilizer amounts in northwest India. Field Crops Research. 134: 59-70.

Mahajan, G., Ramesha, M.S. and Kaur, R. (2011). Screening for weed competitiveness in rice-way to sustainable rice production in the face of global climate change. Proceedings of International Conference on Preparing Agriculture for Climate Change, Ludhiana, Feb 6-8, 2011.

Paswan, A., Kumar, R., Kumar, P. and Singh, R.K. (2012). Influence of Metsulfuron-methyl and carfentrazone-ethyl either alone or in combination on weed flora, crop growth and yield in wheat (Triticum aestivum). Madras Agricultural Journal. 99: 560-562.

Raj, S.K., Jose, N., Mathew, R., Sandhyadevi, C.D. and Leenakumary, S. (2013a). Evaluation of Broad Spectrum Herbicide Bispyribac Sodium + Metamifop on Weed Control and Productivity of Direct Seeded Rice in Kuttanad. In: The Role of Weed Science in Suppressing Food Security by 2020. [Bakar, B.H., Kuriniadie, D. and Tjitrosoedirdjo, S. (eds)], Proceedings of $24^{\text {th }}$ Asian-Pacific Weed Science Conference, October 22-25 2013, Bandung, Indonesia, pp. 465-471.

Raj, S.K., Mathew, R., Jose, N. and Leenakumary, S. (2013b). Evaluation of early post emergence and post emergence herbicides on weed control and productivity of directseeded puddled rice in Kuttanad. Madras Agricultural Journal. 100: 738-742.

Rao, A.N., Johnson, D.E., Sivaprasad, B., Ladha, J.K. and Mortimer, A.M. (2007). Weed management in direct-seeded rice. Advances in Agronomy. 93: 153-255.

Rickman, J.F. (2002). Manual for Laser Land Leveling. Rice-Wheat Consortium Technical Bulletin Series 5. Rice-Wheat Consortium for the Indo-Gangetic Plains, New Delhi, India, $24 \mathrm{p}$.

Singh, P., Singh, P., Singh, R., Singh, K.N. (2007a). Efficacy of new herbicides in transplanted rice under temperate conditions of Kashmir. Indian Journal of Weed Science. 39(3 and 4): $167-171$.

Singh, G. (2008). Integrated Weed Management in Direct-seeded Rice. In: Direct Seeding of Rice and Weed Management in the Irrigated Rice-wheat Cropping System of the IndoGangetic Plains, [Singh, Y., Singh, V.P., Chauhan, B., Orr, A., Mortimer, A.M., Johnson, D. E. and Hardy, B (eds)], IRRI, Los Banos, Phillippines, pp.161-175.

Singh, G., Singh, O.P., Kumar, V. and Kumar, T. (2008). Effect of methods of establishment and tillage practices on the productivity of rice (Oryza sativa)-wheat (Triticum astivum) cropping system. Indian Journal of Agricultural Sciences. 78: 163-166.

Singh, G., Singh, V.P. and Singh, M. (2004). Effect of almix and butachlor alone and in combinations on transplanted rice and associated weeds. Indian Journal of Weed Science. 36: 64-67.

Singh, S., Chokkar, R.S., Gopal, R., Ladha, J. and Singh, M. (2009). Integrated weed management: A key to success for direct seeded rice in Indo-gangetic Plains. In: Integrated Crop and Resource Management in Rice -Wheat System of South Asia. IRRI, Los Banos, Phillipines. pp. 261-278. 
Singh, S., Ladha, J.K., Gupta, R.K., Bhusan, L., Rao, A.N., Sivaprasad, B. and Singh, P.P. (2007). Evaluation of mulching, intecropping with sesbania and herbicide use for weed management in dry-seeded rice. Crop Protection. 26(4): 518-524.

Singh, S., Singh, G., Singh, V.P. and Singh, A.P. (2005). Effect of establishment methods and weed management practices on weeds and rice in rice-wheat system. Indian Journal of Weed Science. 37(1 and 2): 51-57.

Singh, V., Jat, M.L., Ganie, Z.A., Chauhan, B.S. and Gupta, R.K. (2016). Herbicide options for effective weed management in dry direct-seeded rice under scented rice-wheat rotation of western Indo-Gangetic Plains. Crop Protection. 81: 168-176.

Singh, V.P., Dhyani, V.C., Tripathi, N. and Kumar, A. (2011). Effect of Establishment Method and Tillage of Rice and Wheat in the Rice-wheat System of the Indo Gangetic Plains (IGP) of India. In: Proceedings of $5^{\text {th }}$ World Congress of Conservation Agriculture incorporating $3^{\text {rd }}$ farming Systems Design Conference, 26-29 September 2011 Brisbane, Australia.

Singh, V.P., Singh, S.P., Dhyani, V.C., Banga, A., Kumar, A., Satyawali, K. and Bisht, N. (2016). Weed management in directseeded rice. Indian Journal of Weed Science. 48(3): 233246.

Singh, V.P., Singh, S.P., Dhyani, V.C., Kumar, A. and Singh, M.K. (2010). Bio-efficacy of azimsulfuron against sedges in direct seeded rice. Indian Journal of Weed Science. 42(1 and 2): 98-101.
Singh, V.P., Singh, S.P., Dhyani, V.C., Tripathi, N., Banga, A. and Yadav, V.R. (2013). Effect of Establishment Methods on Shifting of Weed Flora in Rice-wheat Cropping System. $24^{\text {th }}$ Asian-Pacific Weed Science Society Conference, October 22-25, 2013, Bandung, Indonesia.

Singh, V.P., Singh, S.P., Kumar, A., Banga, A. and Tripathi, N. (2012). Effect of monsoon and weed management on growth and yield of direct seeded rice. Indian Journal of Weed Science. 44(3): 147-150.

Sunil, C.M., Shekara, B.G., Kalyanmurthy, K.N. and Shankaralingapa, B.C. (2010). Growth and yield of aerobic rice as influenced by integrated weed management practices. Indian Journal of Weed Science. 42(3 and 4): 180-183.

Thi, H.L., Man, L.H. Chin, D.V., Auld, B.A. and Hetherington, S.D. (1999). Research on Some Fungi to Control Barnyard Grass and Red Sprangle Top in Rice. In: Proceedings of the $17^{\text {th }}$ Asian-Pacific Weed Science Society Conference, Bangkok, Thailand. p. 562-566.

Walia, U.S. (2006). Weed Management. New Delhi: Kalyani Publishers.

Wassmann, R., Neue, H.U., Ladha, J.K. and Aulakh, M.S. (2004). Mitigating greenhouse gas emissions from rice-wheat cropping systems in Asia. Environment, Development and Sustainability. 6: 65-90.

Zhao, D.L., Atlin, G.N., Bastiaans, L. and Spiertz, J.H.J. (2006). Cultivar weed competitiveness in aerobic rice: Heritability, correlated traits and the potential for in direct selection in weed-free environment. Crop Science. 46: 372-380. 